\title{
ANALYSIS ON THE COLLECTIVE EFFICACY PERCEPTIONS OF HANDBALL PLAYERS IN TERMS OF SOME VARIABLES ${ }^{1}$
}

\section{HENTBOL OYUNCULARININ KOLEKTIF YETERLIKK ALGILARININ BAZI DEĞIŞKENLER AÇISINDAN İNCELENMESI}

\author{
Ali Serdar YÜCEL ${ }^{1}$, Özgür, KARATAŞ ${ }^{2}$, Yüksel SAVUCU ${ }^{3}$, Serdar ORHAN ${ }^{4}$ \\ ${ }^{1-3-4}$ University of Firat Faculty, of Sports Sciences, Elazig / Turkey \\ ${ }^{2}$ Inönü University, School of Physical Education and Sports BESYO, Malatya / Turkey
}

Öz: Amaç: Bu araştırmanın amacı; Türkiye'deki üst düzey hentbol takımlarında mücadele eden sporcuların (Süper lig, 1. Lig ve 2.Lig) kolektif yeterlik düzeylerinin farklı değişkenler açısından incelenmesidir. Yöntem: Araştırma Süper lig, 1. Lig ve 2. Lig'de yer alan 65 takım içerisinden rasgele yöntemle belirlenmis 483 sporcu üzerinde gerçeklesțirilmiștir. Çalışmada kullanılan anket daha önceden farklı bir çalışmada kullanılmış olup, güvenirliliği sağlanmış bir ankettir. Anketin ilk bölümünde katılımcılara kişisel bilgileri (cinsiyet, eğitim, yaş, takımdaki pozisyonları vs.) sınıflayıcı ölçekle tanımlayıcı değişkenler olarak sorulmuştur. İkinci bölümde ise takım için kolektif bilinç hakkında 7 adet görüş yöneltilmiş ve görüşleri 5'li likert ölçekle sorgulanmıştır. Cronbach's Alpha kat sayısı olarak 0,921 değeri elde edilmiş̦tir. Analiz kapsamın$\mathrm{da}$, betimleyici istatistikler, güvenilirlik analizi, Jonckheere terpstra, t-testi analizi, Varyans analizi (ANOVA), Kruskall Wallis, Man Whitney ve tukey testi uygulanmıştır. Bulgular: Kolektif yeterlilik ölçeğinin yaşa göre farklılaştığı ve en yüksek ortalamanın 16-21 grubuna ait olduğu saptanmıştır. Ayrıca eğitime ve spor süresine göre de farklılık olduğu ve bu eğitim değişkenine göre en yüksek ortalamanın üniversite grubu ve spor süresine göre de 4-7 yıl grubuna ait olduğu bulunmuştur. Sonuç: Çalışma sonunda, katılımcıların kolektif yeterlilik ölçeğine ilişkin görüşlerinin yaş, eğitim durumu, antrenör cinsiyeti ve spor süresine göre farklılık gösterdiği, bunun yanında cinsiyet, oynanan lig, lisans durumu ve takımdaki pozisyona göre farklılık göstermediği sonucuna ulaşılmıştır.

Anahtar Kelimeler: Hentbol, Kolektif Yeterlilik, Sporcu, Lig

Doi: 10.17363/SSTB.2017.1.001
Abstract: Aim: The purpose of this research is to analyze the collective efficacy levels of the athletes playing in top-level handball teams in Turkey (Super League, First League and Second League) in terms of different variables. Method: The research was conducted on a total of randomly selected 483 athletes within 65 teams ranking among Super League, First League and Second League. The questionnaires used in this study were previously used in another study and its reliability was ensured. In the first part of the questionnaire, personal information (sex, education, positions in the team etc.) was asked to the participants as descriptive variables with classificatory variable. In the second part, 7 opinions were directed regarding the collective consciousness for the team and the opinions were questioned with a 5-point Likert scale. 0.921 was ensured as the Cronbach's Alpha coefficient. Descriptive statistics, reliability analysis, Jonckheere terpstra, t-test analysis, Variance analysis (ANOVA), Kruskall Wallis, Man Whitney and tukey test were applied within the scope of the analysis. Results: It has been determined that the collective efficacy scale differs by age and the highest average belongs to the group of 16-21. Moreover, it has been established that it differs by the education and duration of sports; the highest average belongs to the university group by this education variable and to the group of 4-7 years by the duration of sports. Conclusion: At the end of the study, it has been concluded that the opinions of the participants concerning the collective efficacy scale differ by age, education, sex of the trainer and duration of sports; but they don't differ by sex, the league played, license and the position in the team.

Key Words: Handball, Collective Efficacy, Athlete, League

(1) Corresponding Author: Ali Serdar YÜCEL, University of Firat Faculty, of Sports Sciences, Elazig / Turkey, alsetu_23@hotmail.com, Received: 19/12/2016, Revision date: 11/02/2017, Accepted: 25/03/2017 Type of article (Research) Conflict of Interest: None / "None of Ethics Committee" 


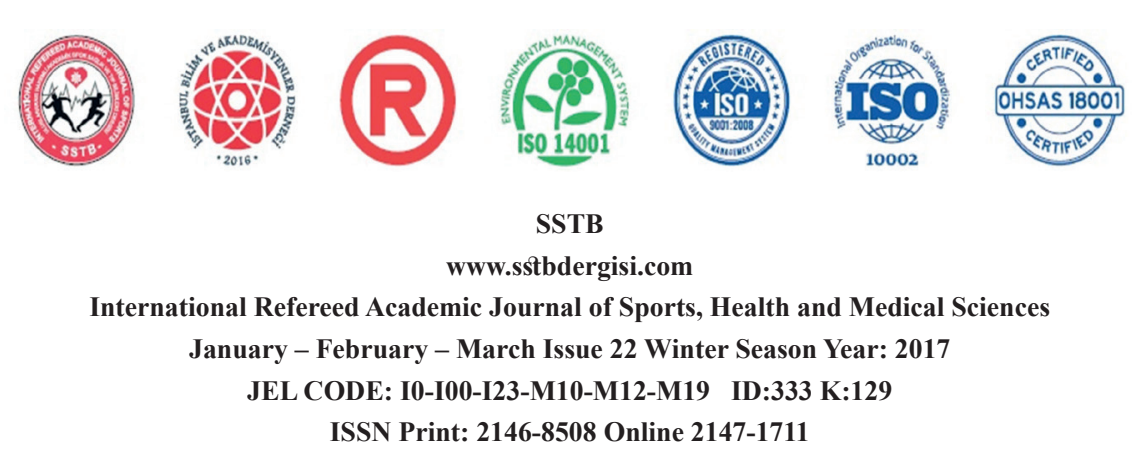

(ISO 18001-OH-0090-13001706 / ISO 14001-EM-0090-13001706 / ISO 9001-QM-0090-13001706 / ISO 10002-CM-0090-13001706) (TRADEMARK)

(2015/04315- 2015-GE-18972)

\section{INTRODUCTION}

One of the important variables affecting the performance levels of the groups is the competence perception which is frequently emphasized in recent years. The perception of individual on his or her capacity to do work is called self-efficacy and the perception of the individual on the capacity of a group in which the individual is a member - to do work is expressed as collective efficacy (Öcel, 2002: 2 ).

In order for a community to become a group, it is necessary to provide an exchange of interaction, emotion and information. The more intense this interaction is, the higher the group dynamics will be (Moralı and Doğan, 1997: 8 ).

The collective efficacy is the competence of a group to share the expectations and success laid on the members. These two concepts are highly important for the success of a sports team. Because collective efficacy shows how a team works together and how much each group member believes in success. Therefore, the factors of success in developing skills based on collective efficacy and process are analyzed as different but interrelated facts (Zaccaro et al., 1995: 305-328 ).

The concept of collective efficacy is one of the most important concepts of Bandura's Social Cognitive Theory and an extension of the self-efficacy concept for teams and communities (Bandura, 1997; Bandura, 2000; Bandura, 2012). The researches conducted indicate that both self-efficacy and collective efficacy perceptions affect the expectations and motivation levels, accordingly and may increase the individual's performance. According to the social cognitive theory, there is a strong relation between the self-efficacy levels of individuals and their performance (Wood and Bandura 1989: 361-384).

The studies on the group dynamic examining the importance of group environment and its changing nature have an indispensable importance for the studies of social psychology and have a great place in research fields. The number of studies carried out in order to examine the dynamics that take place within a group structure in the field of social psychology has shown a serious increase (Horn, 2002: 309-355).

The integration of the team athletes as a result of the relations easily affected by external factors will enable the team's goal orientations to become clear. Due to the fact that the goal orientations within the team determine the performance of tasks and individuals who constitute the team performance, motivational climate can be affected from many internal and external factors, namely mastery and performance (Vlachopoulos and Karageorghis, 2005: 113-132). In the research of Ramzani- 


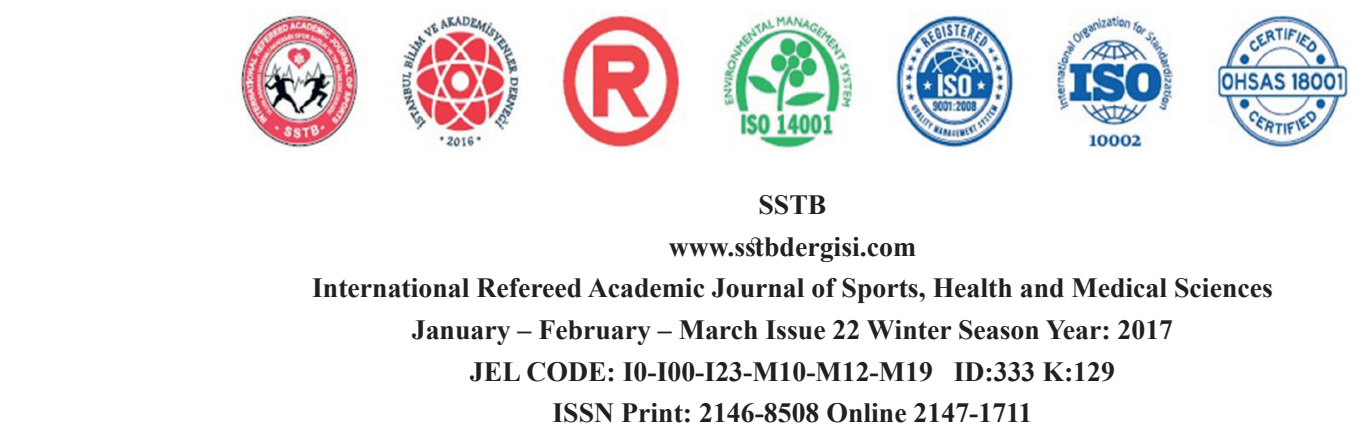

(ISO 18001-OH-0090-13001706 / ISO 14001-EM-0090-13001706 / ISO 9001-QM-0090-13001706 / ISO 10002-CM-0090-13001706) (TRADEMARK)

(2015/04315- 2015-GE-18972)

nezhad et al. (2009), it is put forth that there is a significant relation between collective efficacy and group unity and it is highlighted that the solidarity in the sports teams significantly affects the group unity and collective efficacy needed in the process of contributing to the team's performance.

The integration of individual skills and abilities in team sports around a common goal and the belief to achieve these goals at team level are perceived as collective efficacy. Thus, collective efficacy has an important effect on team performance. As the best performance of teams and their success afterwards depend on group unity and the belief in team's efficacy. Just as self-efficacy is effective on individual performance, collective efficacy is also influential on team performance (Katz-Navon and Erez, 2005: 437-465). It is very important for individuals to believe that teams will be successful at a sufficient level before the teams actually succeed. As positive collective efficacy may affect the behaviors of athletes (Safkan, 2010: 8). People's belief in collective efficacy affects the way in which they will try to actualize the social future, how much effort they will make for it and the strength they will put forth when collective efforts fail to yield results (Kurt, 2012: 203 ). Unity or cohesiveness is evaluated as an important factor in success of groups. Similarly, unity and integrity play an important role in sports.
Because in order for teams to be successful, skills and efforts should be combined and all members of the team should come together. Collective efficacy is vital for success as it directly affects the team's integrity (Carron et al., 2007: 117-139). It is emphasized that the trust of the athletes towards each other and belief of success in team sports (collective efficacy) may be effective on performance (Yücel et al., 2013: 1403).

\section{AIM}

The purpose of this research is to analyze the collective efficacy levels of the athletes playing in top-level handball teams in Turkey (Super League, First League and Second League) in terms of different variables.

\section{METHOD}

In this study, a two-part questionnaire including questions about collective consciousness levels and demographic characteristics was applied. The questionnaire used in this study was previously used in another study and its reliability was ensured. Survey method was used in this study. In the first part, the participants were asked about their personal information (sex, education, marital status, age, positions in the team etc.) as descriptive variables with a classifying scale. In the second part, 7 opinions were directed about the collective consciousness for the team and the opinions were questioned with 5-point Likert 


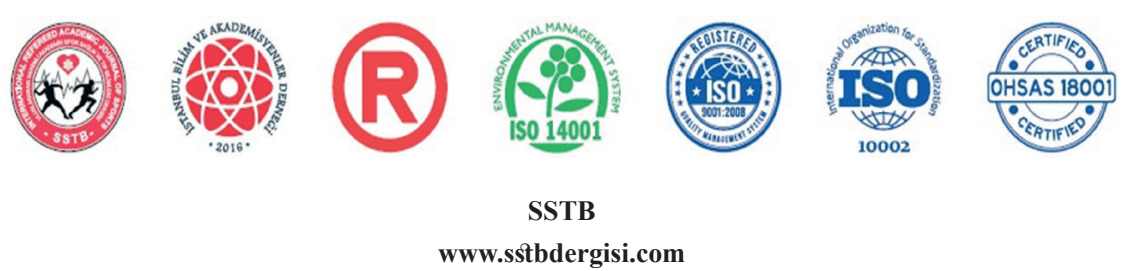

International Refereed Academic Journal of Sports, Health and Medical Sciences

January - February - March Issue 22 Winter Season Year: 2017

JEL CODE: I0-I00-I23-M10-M12-M19 ID:333 K:129

ISSN Print: 2146-8508 Online 2147-1711

(ISO 18001-OH-0090-13001706 / ISO 14001-EM-0090-13001706 / ISO 9001-QM-0090-13001706 / ISO 10002-CM-0090-13001706) (TRADEMARK)

(2015/04315- 2015-GE-18972)

scale. The questionnaire forms were applied to the athletes playing in various leagues during the 2014-2015 season as a face-to-face interview before or after the competition. "Collective Efficacy Scale" developed by Riggs, Warka, Babasa, Betancoyrt and Hooker (1994) with the purpose of determining the collective efficacy level was used in our research.

\section{DATA ANALYSIS}

Descriptive statistics, reliability analysis, Factor Analysis, t-test analysis, Variance analysis (ANOVA), Jonckheere terpstra, Kruskall Wallis, Kolmogorov Smirnov, Man Whitney and Tukey test were applied within the scope of analysis. The value of 0.921 was obtained as the Cronbach's Alpha coefficient.

\section{Research Hypotheses}

H1: The opinions on collective efficacy don't differ by sex.
H2: The opinions on collective efficacy don't differ by age.

H3: The opinions on collective efficacy don't differ by education.

H4: The opinions on collective efficacy don't differ by income.

H5: The opinions on collective efficacy don't differ by the duration of sports.

H6: The opinions on collective efficacy don't differ by the league.

H7: The opinions on collective efficacy don't differ by the license.

H8: The opinions on collective efficacy don't differ by the position.

H9: The opinions on collective efficacy don't differ by the sex of trainer.

\section{FINDINGS}

\begin{tabular}{cc}
\hline \multicolumn{2}{c}{ Table 1. Reliability Analysis } \\
\hline Cronbach's Alpha & Number of Items \\
\hline, 921 & 7 \\
\hline
\end{tabular}

Concerning the results of reliability analysis, it has been determined that 7 items included in the analysis are at very high confidence level. 


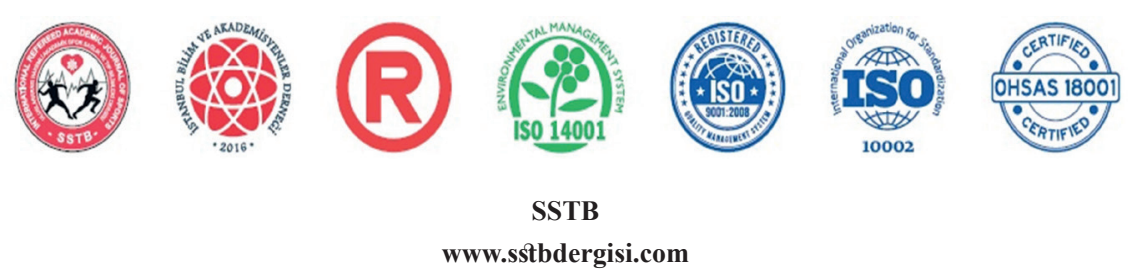

International Refereed Academic Journal of Sports, Health and Medical Sciences

January - February - March Issue 22 Winter Season Year: 2017

JEL CODE: I0-I00-I23-M10-M12-M19 ID:333 K:129

ISSN Print: 2146-8508 Online 2147-1711

(ISO 18001-OH-0090-13001706 / ISO 14001-EM-0090-13001706 / ISO 9001-QM-0090-13001706 / ISO 10002-CM-0090-13001706)

(TRADEMARK)

(2015/04315- 2015-GE-18972)

Table 2. Demographic and Descriptive Statistics of The Participants

\begin{tabular}{|c|c|c|c|}
\hline Variables & & Frequency & Column N \% \\
\hline \multirow[t]{2}{*}{ Your sex? } & Female & 263 & $54 \%$ \\
\hline & Male & 220 & $46 \%$ \\
\hline \multirow[t]{4}{*}{ Your age? } & Below the age of 15 & 13 & $3 \%$ \\
\hline & $16-21$ & 299 & $62 \%$ \\
\hline & $22-27$ & 140 & $29 \%$ \\
\hline & 34 and over & 31 & $6 \%$ \\
\hline \multirow[t]{3}{*}{ Your educational background? } & High school & 118 & $24 \%$ \\
\hline & University & 349 & $72 \%$ \\
\hline & Post graduate & 16 & $3 \%$ \\
\hline \multirow[t]{2}{*}{ Your marital status? } & Single & 440 & $91 \%$ \\
\hline & Married & 43 & $9 \%$ \\
\hline \multirow[t]{6}{*}{ Your income or your family's income? } & $500 \mathrm{TL}$ and less & 24 & $5 \%$ \\
\hline & 501-999 TL & 69 & $14 \%$ \\
\hline & $1000-1500 \mathrm{TL}$ & 177 & $37 \%$ \\
\hline & $1501-3000 \mathrm{TL}$ & 155 & $32 \%$ \\
\hline & $3001-5000 \mathrm{TL}$ & 43 & $9 \%$ \\
\hline & $5001 \mathrm{TL}$ and more & 15 & $3 \%$ \\
\hline \multirow[t]{6}{*}{ How many years have you been doing sports? } & $1-3$ years & 46 & $10 \%$ \\
\hline & 4-7 years & 104 & $22 \%$ \\
\hline & $7-11$ years & 188 & $39 \%$ \\
\hline & $12-15$ years & 113 & $23 \%$ \\
\hline & 16-19 years & 21 & $4 \%$ \\
\hline & 20 years and more & 11 & $2 \%$ \\
\hline \multirow[t]{3}{*}{ What is the league you play? } & Super League & 100 & $21 \%$ \\
\hline & $1^{\text {st }}$ League & 259 & $54 \%$ \\
\hline & $2^{\text {nd }}$ League & 124 & $26 \%$ \\
\hline
\end{tabular}




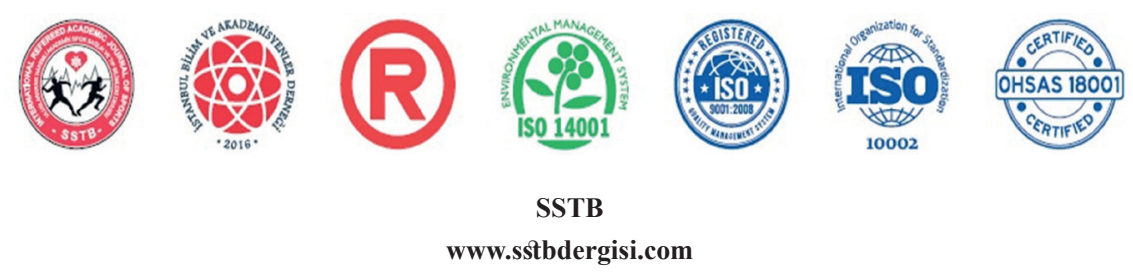

International Refereed Academic Journal of Sports, Health and Medical Sciences

January - February - March Issue 22 Winter Season Year: 2017

JEL CODE: I0-I00-I23-M10-M12-M19 ID:333 K:129

ISSN Print: 2146-8508 Online 2147-1711

(ISO 18001-OH-0090-13001706 / ISO 14001-EM-0090-13001706 / ISO 9001-QM-0090-13001706 / ISO 10002-CM-0090-13001706)

(TRADEMARK)

(2015/04315- 2015-GE-18972)

\begin{tabular}{|c|c|c|c|}
\hline \multirow[t]{4}{*}{ Your mother's educational background? } & Primary school & 170 & $35 \%$ \\
\hline & Secondary school & 121 & $25 \%$ \\
\hline & High school & 129 & $27 \%$ \\
\hline & University & 63 & $13 \%$ \\
\hline \multirow[t]{5}{*}{ Your father's educational background? } & Primary school & 98 & $20 \%$ \\
\hline & Secondary school & 107 & $22 \%$ \\
\hline & High school & 147 & $31 \%$ \\
\hline & University & 116 & $24 \%$ \\
\hline & Post graduate & 12 & $3 \%$ \\
\hline \multirow{4}{*}{$\begin{array}{l}\text { How many years have you been actively (licen- } \\
\text { sed) interested in sports? }\end{array}$} & $1-3$ years & 117 & $24 \%$ \\
\hline & 4-7 years & 217 & $45 \%$ \\
\hline & 7-11 years & 111 & $23 \%$ \\
\hline & $12-15$ years & 38 & $8 \%$ \\
\hline \multirow[t]{3}{*}{ Total number of athletes in your team? } & 1.00 & 210 & $43 \%$ \\
\hline & 2.00 & 247 & $51 \%$ \\
\hline & 3.00 & 26 & $5 \%$ \\
\hline \multirow{6}{*}{$\begin{array}{l}\text { How many years have you been playing in this } \\
\text { team? }\end{array}$} & $1-3$ years & 120 & $25 \%$ \\
\hline & 4-7 years & 126 & $26 \%$ \\
\hline & 7-11 years & 72 & $15 \%$ \\
\hline & $12-15$ years & 97 & $20 \%$ \\
\hline & 16-19 years & 49 & $10 \%$ \\
\hline & 20 years and more & 19 & $4 \%$ \\
\hline \multirow[t]{2}{*}{ Your position in the team? } & Main & 306 & $63 \%$ \\
\hline & Substitute & 177 & $37 \%$ \\
\hline \multirow[t]{2}{*}{ Sex of your trainer? } & Female & 79 & $16 \%$ \\
\hline & Male & 404 & $84 \%$ \\
\hline
\end{tabular}




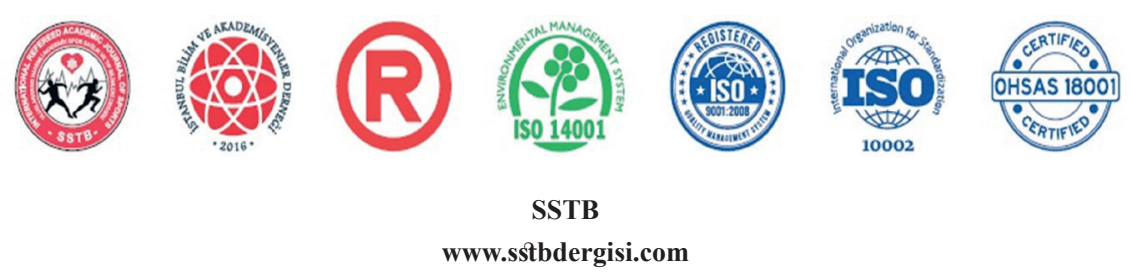

International Refereed Academic Journal of Sports, Health and Medical Sciences January - February - March Issue 22 Winter Season Year: 2017

JEL CODE: I0-I00-I23-M10-M12-M19 ID:333 K:129

ISSN Print: 2146-8508 Online 2147-1711

(ISO 18001-OH-0090-13001706 / ISO 14001-EM-0090-13001706 / ISO 9001-QM-0090-13001706 / ISO 10002-CM-0090-13001706) (TRADEMARK)

(2015/04315- 2015-GE-18972)

Table 3. Analyses for Different Variables on Scale of Participants

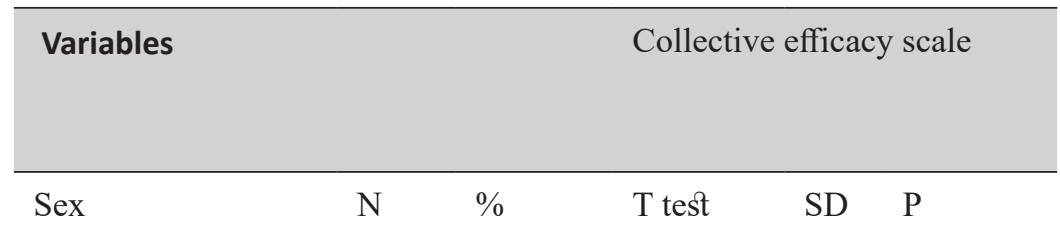

\begin{tabular}{llllll}
\cline { 1 - 5 } Female & 263 & $54 \%$ & -.823 & 481 & .411 \\
\cline { 1 - 5 } Male & 220 & $46 \%$ & & & \\
\hline Age & $\mathrm{N}$ & $\%$ & Anova & SD & $\mathrm{p}$ \\
\hline
\end{tabular}

\begin{tabular}{lll}
\hline Below the age of 15 & 13 & $3 \%$ \\
\hline $16-21$ & 299 & $62 \%$ \\
\hline $22-27$ & 140 & $29 \%$ \\
\hline
\end{tabular}

\begin{tabular}{llllll}
\hline 34 and higher & 31 & $6 \%$ & & & \\
\hline Education & $\mathrm{N}$ & $\%$ & $\begin{array}{l}\text { Jonc- } \\
\text { kheere }\end{array}$ & SD & $\mathrm{p}$
\end{tabular}

terpstra

\begin{tabular}{|c|c|c|c|c|c|}
\hline High school & 118 & $24 \%$ & \multirow[t]{3}{*}{6.869} & \multirow[t]{3}{*}{2} & \multirow[t]{3}{*}{0.000} \\
\hline University & 349 & $72 \%$ & & & \\
\hline Post graduate & 16 & $3 \%$ & & & \\
\hline Level of income & $\mathrm{N}$ & $\%$ & $\begin{array}{l}\text { Kruskal } \\
\text { Wallis }\end{array}$ & SD & $\mathrm{p}$ \\
\hline
\end{tabular}

\begin{tabular}{|c|c|c|c|c|c|}
\hline 500 and less & 24 & $5 \%$ & 9.049 & 5 & 0.107 \\
\hline 501-999 TL & 69 & $14 \%$ & & & \\
\hline 1000-1500 TL & 177 & $37 \%$ & & & \\
\hline $1501-3000 \mathrm{TL}$ & 155 & $32 \%$ & & & \\
\hline 3001-5000 TL & 43 & $9 \%$ & & & \\
\hline $5001 \mathrm{TL}$ and more & 15 & $3 \%$ & & & \\
\hline Duration of sports & $\mathrm{N}$ & $\%$ & Anova & $\mathrm{SD}$ & $\mathrm{p}$ \\
\hline
\end{tabular}




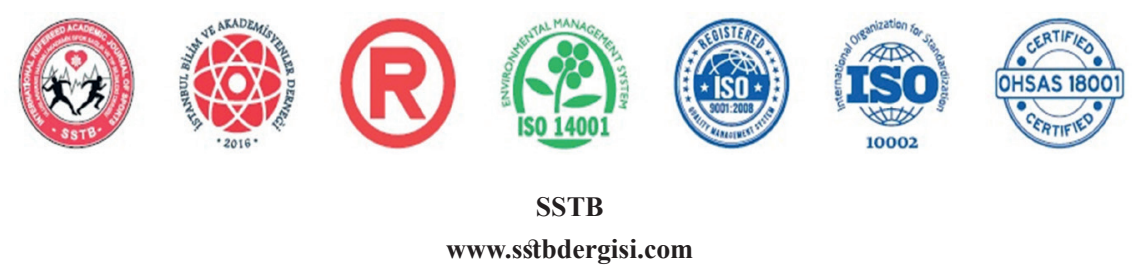

International Refereed Academic Journal of Sports, Health and Medical Sciences January - February - March Issue 22 Winter Season Year: 2017

JEL CODE: I0-I00-I23-M10-M12-M19 ID:333 K:129

ISSN Print: 2146-8508 Online 2147-1711

(ISO 18001-OH-0090-13001706 / ISO 14001-EM-0090-13001706 / ISO 9001-QM-0090-13001706 / ISO 10002-CM-0090-13001706) (TRADEMARK)

(2015/04315- 2015-GE-18972)

\begin{tabular}{|c|c|c|c|c|c|}
\hline 1-3 years & 46 & $10 \%$ & \multirow[t]{6}{*}{3.883} & \multirow[t]{6}{*}{5} & \multirow[t]{6}{*}{0.002} \\
\hline 4-7 years & 104 & $22 \%$ & & & \\
\hline 7-11 years & 188 & $39 \%$ & & & \\
\hline $12-15$ years & 113 & $23 \%$ & & & \\
\hline $16-19$ years & 21 & $4 \%$ & & & \\
\hline 20 years and more & 11 & $2 \%$ & & & \\
\hline League & $\mathrm{N}$ & $\%$ & Anova & $\mathrm{SD}$ & $\mathrm{p}$ \\
\hline Super league & 100 & $21 \%$ & \multirow[t]{3}{*}{0.531} & \multirow[t]{3}{*}{2} & \multirow[t]{3}{*}{0.588} \\
\hline $1^{\text {st }}$ League & 259 & $54 \%$ & & & \\
\hline $2^{\text {nd }}$ League & 124 & $26 \%$ & & & \\
\hline Licensed & $\mathrm{N}$ & $\%$ & $\begin{array}{l}\text { Kruskal } \\
\text { Wallis }\end{array}$ & $\mathrm{SD}$ & $\mathrm{p}$ \\
\hline
\end{tabular}

\begin{tabular}{|c|c|c|c|c|c|}
\hline $1-3$ years & 117 & $24 \%$ & \multirow[t]{4}{*}{1.231} & \multirow[t]{4}{*}{3} & \multirow[t]{4}{*}{0.745} \\
\hline 4-7 years & 217 & $45 \%$ & & & \\
\hline 7-11 years & 111 & $23 \%$ & & & \\
\hline $12-15$ years & 38 & $8 \%$ & & & \\
\hline Position & $\mathrm{N}$ & $\%$ & t-test & $\mathrm{SD}$ & $\mathrm{P}$ \\
\hline Main & 306 & $63 \%$ & \multirow[t]{2}{*}{1.758} & \multirow[t]{2}{*}{1} & \multirow[t]{2}{*}{0.080} \\
\hline Substitute & 177 & $37 \%$ & & & \\
\hline Trainer & $\mathrm{N}$ & $\%$ & $\begin{array}{l}\text { Man } \\
\text { Whitney }\end{array}$ & $\mathrm{SD}$ & $\mathrm{p}$ \\
\hline Female & 79 & $16 \%$ & \multirow[t]{2}{*}{2.960} & \multirow[t]{2}{*}{1} & \multirow[t]{2}{*}{0.003} \\
\hline Male & 404 & $84 \%$ & & & \\
\hline
\end{tabular}




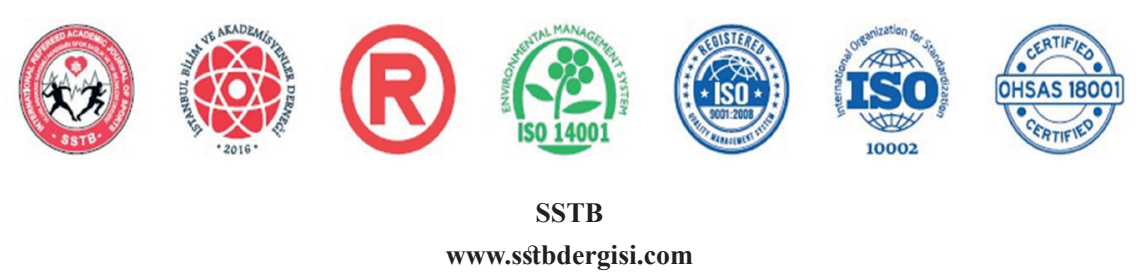

International Refereed Academic Journal of Sports, Health and Medical Sciences

January - February - March Issue 22 Winter Season Year: 2017

JEL CODE: I0-I00-I23-M10-M12-M19 ID:333 K:129

ISSN Print: 2146-8508 Online 2147-1711

(ISO 18001-OH-0090-13001706 / ISO 14001-EM-0090-13001706 / ISO 9001-QM-0090-13001706 / ISO 10002-CM-0090-13001706) (TRADEMARK)

(2015/04315- 2015-GE-18972)

Table 4. Descriptive Statistics of the Participants

\begin{tabular}{|c|c|c|c|}
\hline & $\mathrm{N}$ & Mean & Std. Deviation \\
\hline $\begin{array}{l}\text { The skills of my team mates are above the } \\
\text { average. }\end{array}$ & 483 & 2.9420 & 1.23266 \\
\hline $\begin{array}{l}\text { This team is weaker than other teams in the } \\
\text { same sports. }\end{array}$ & 483 & 2.2961 & 1.06302 \\
\hline $\begin{array}{l}\text { This team doesn't have the capacity to show } \\
\text { adequate performance. }\end{array}$ & 483 & 2.2609 & 1.12969 \\
\hline My team mates have excellent athletic skills. & 483 & 2.8861 & 1.11640 \\
\hline $\begin{array}{l}\text { Some of my team mates should be excluded } \\
\text { from the team due to the lack of athletic } \\
\text { skills. }\end{array}$ & 483 & 2.5652 & 1.20226 \\
\hline My team isn’t good enough. & 483 & 2.3540 & 1.23273 \\
\hline $\begin{array}{l}\text { Some athletes in the team can't play very } \\
\text { well. }\end{array}$ & 483 & 2.9482 & 1.26204 \\
\hline
\end{tabular}

\section{H1: The opinions on collective efficacy don't differ by sex.}

Concerning the opinions on collective efficacy by sex, Sig value has been found to be higher than 0.05 ; therefore, the hypothesis will be accepted. Accordingly,

- Collective efficacy scale doesn't differ by sex.

\section{H2: The opinions on collective efficacy don't differ by age.}

Concerning the opinions on collective efficacy by age, Sig value has been found to be lower than 0.05 ; therefore, the hypothesis will be rejected. Accordingly,

- Collective efficacy scale differs by age. The highest average belongs to 16-21 group.

\section{H3: The opinions on collective efficacy don't differ by education.}

Concerning the opinions on collective efficacy by education, Sig value has been found to be lower than 0.05 ; therefore, the hypothesis will be rejected. Accordingly, 


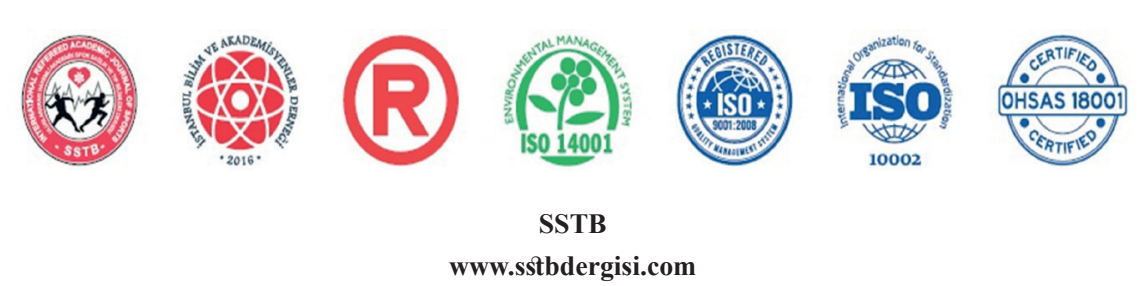

International Refereed Academic Journal of Sports, Health and Medical Sciences

January - February - March Issue 22 Winter Season Year: 2017

JEL CODE: I0-I00-I23-M10-M12-M19 ID:333 K:129

ISSN Print: 2146-8508 Online 2147-1711

(ISO 18001-OH-0090-13001706 / ISO 14001-EM-0090-13001706 / ISO 9001-QM-0090-13001706 / ISO 10002-CM-0090-13001706) (TRADEMARK)

(2015/04315- 2015-GE-18972)

- Collective efficacy scale differs by education. The highest average belongs to the university group.

H4: The opinions on collective efficacy don't differ by income.

Concerning the opinions on collective efficacy by income, Sig value has been found to be higher than 0.05 ; therefore, the hypothesis will be accepted. Accordingly,

- Collective efficacy scale doesn't differ by income.

H5: The opinions on collective efficacy don't differ by the duration of sports.

Concerning the opinions on collective efficacy by the duration of sports, Sig value has been found to be lower than 0.05 ; therefore, the hypothesis will be rejected. Accordingly,

- Collective efficacy scale differs by the duration of sports. The highest average belongs to the group of 4-7 years.

H6: The opinions on collective efficacy don't differ by the league.

Concerning the opinions on collective efficacy by the league, Sig value has been found to be higher than 0.05 ; therefore, the hypothesis will be accepted. Accordingly,

- Collective efficacy scale doesn't differ by the league.
H7 The opinions on collective efficacy don't differ by the license.

Concerning the opinions on collective efficacy by the license, Sig value has been found to be lower than 0.05 ; therefore, the hypothesis will be rejected. Accordingly,

- Collective efficacy scale doesn't differ by the license.

H8: The opinions on collective efficacy don't differ by the position.

Concerning the opinions on collective efficacy by the position, Sig value has been found to be higher than 0.05 ; therefore, the hypothesis won't be rejected. Accordingly,

- Collective efficacy scale doesn't differ by the position.

H9: The opinions on collective efficacy don't differ by the sex of trainer.

Concerning the opinions on collective efficacy by the sex of trainer, Sig value has been found to be lower than 0.05 ; therefore, the hypothesis will be rejected. Accordingly,

- Collective efficacy scale differs by the sex of trainer. The highest average belongs to female group.

\section{DISCUSSION}

The purpose of this research is to analyze the collective efficacy levels of the athletes 


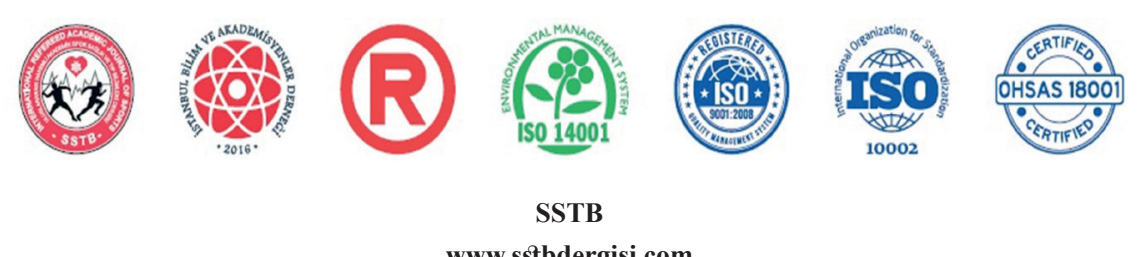

www.sstbdergisi.com

International Refereed Academic Journal of Sports, Health and Medical Sciences

January - February - March Issue 22 Winter Season Year: 2017

JEL CODE: I0-I00-I23-M10-M12-M19 ID:333 K:129

ISSN Print: 2146-8508 Online 2147-1711

(ISO 18001-OH-0090-13001706 / ISO 14001-EM-0090-13001706 / ISO 9001-QM-0090-13001706 / ISO 10002-CM-0090-13001706)

(TRADEMARK)

(2015/04315- 2015-GE-18972)

playing in top-level handball teams in Turkey (Super League, First League and Second League) in terms of different variables. When the general averages of the participants related to the scale are examined, it can be stated that their collective efficacy levels are high.

According to the results, it has been determined that $54 \%$ of the athletes (263 people) are female and $46 \%$ is male (220 people); $62 \%$ is in the age group of 16-21 (299 people), $72 \%$ is university graduate (349 people), the sports age of $39 \%$ (188 people) is $7-11$, income level of $37 \%$ (177 people) is $1000-1500$ $\mathrm{TL}$ and $45 \%$ has been interested in sports as licensed athletes for 4-7 years.

Collective efficacy scale doesn't differ by sex. In the study of Yücel et. al. (2013) conducted on table tennis players, it has been determined that female athletes trust the skills of their team mates less than male athletes. In the study of Atalay et. al. (2015) performed on futsal players, it has been stated that the items of "This team is weaker than other teams in the same sports" (Male>Female) and "My team isn't good enough" (Male>Female) differ by sex.

In study, collective efficacy scale differs by age. The highest average belongs to the age group of 16-21. Yücel et. al. (2013) has established in their study that as the age increases, the trust in the team and skills of team players increases positively. In the study of Atalay et. al. (2015) conducted on futsal players, it has been indicated that the item of "The skills of my team mates are above the average" differs by the age group of 17-20.

Collective efficacy scale doesn't differ by the license. It has been ascertained in the study of Yücel et. al. (2013) that the longer the duration of being a licensed athlete is, the higher the trust in the team and the skills of team players becomes positively. In the study of Atalay et. al. (2015) conducted on futsal players, differences have been found in some items of the collective efficacy scale.

Collective efficacy scale differs by the duration of sports. The highest average belongs to the group of 4-7 years. In the study of Yücel et. al. (2013), it has been determined that the longer the duration of sports is, the higher the trust in the team and the skills of team players becomes positively. Collective efficacy scale differs by education. The highest average belongs to the university group. Collective efficacy scale differs by the sex of trainer. The highest average belongs to the female group. Collective efficacy levels of the athletes having a female trainer have been found to be higher. Collective efficacy scale doesn't differ by income, league and the position. 


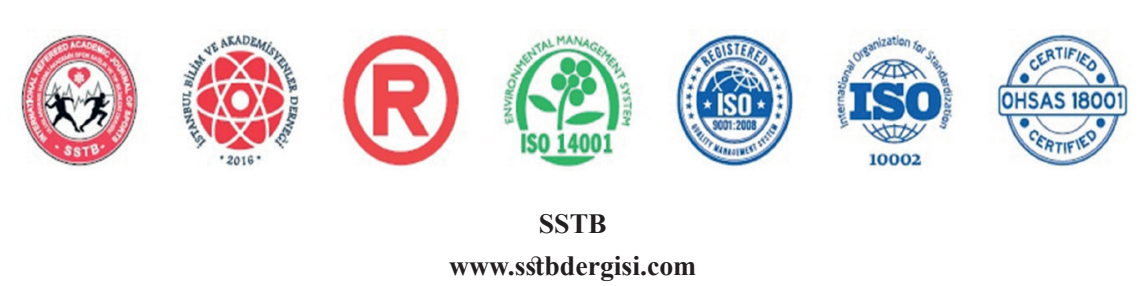

International Refereed Academic Journal of Sports, Health and Medical Sciences

January - February - March Issue 22 Winter Season Year: 2017

JEL CODE: I0-I00-I23-M10-M12-M19 ID:333 K:129

ISSN Print: 2146-8508 Online 2147-1711

(ISO 18001-OH-0090-13001706 / ISO 14001-EM-0090-13001706 / ISO 9001-QM-0090-13001706 / ISO 10002-CM-0090-13001706) (TRADEMARK)

(2015/04315- 2015-GE-18972)

\section{CONCLUSION}

It has been determined in the study that the collective efficacy levels of handball players differ by some variables. As a result, there is a positive relation between collective efficacy and performance. It is essential for athletes to trust each other and their teams in order to achieve and sustain success in team sports. Only a group of skilled athletes isn't enough for a successful team, these skilled athletes should act as a whole, share their responsibilities as required; in short, their collective efficacy beliefs should be high.

\section{REFERENCES}

MORALI, S., DOĞAN, B., (1997). Bireysel ve takım sporlarında takım birlikteliği düzeylerinin karşılaştırılması, Beden Eğitimi ve Spor Bilimleri Dergisi, 2(4): 7-17

ZACCARO, S., BLAIR, V., PETERSON, C., ZAZANIS, M. (1995)., Collective efficacy. In J. Maddux (Ed.), Self-efficacy, adaptation, and adjustment (pg. 305-328). New York: Plenum. Doi: 10.1007/978-14419-6868-5_11

BANDURA, A., (1997). Self efficacy: The exercise of control. New York: W. H. Freeman and Company

BANDURA, A., (2000). Exercise of human agency through collective efficacy. Current
Directions in Psychological Science, 9, 75-78. Doi: https://doi.org/10.1111/14678721.00064

BANDURA, A., (2012). On the functional properties of perceived self efficacy revisited. Journal of Management, 38, 9-44. Doi: $10.1177 / 0149206311410606$

WOOD, R., BANDURA, A., (1989). Social cognitive theory of organizational Management. Academy of Management Review, 14,361-384. Doi: 10.5465/ AMR.1989.4279067

HORN, T.S., (2002). Coaching effectiveness in the sport domain. In T.S. Horn (Ed.), Advances in Sport Psychology (pg. 309355). Champaign, IL: Human Kinetics

VLACHOPOULOS, S.P., KARAGEORGHIS, C.I., (2005). Interaction of external, introjected, and identified regulation with intrinsic motivation in exercise: relationships with exercise enjoyment. Journal of Applied Bio-behavioral Research 10, 113-132. Doi:10.1111/j.1751-9861.2005. tb00007.x

KATZ-NAVON, T.Y., EREZ, M., (2005). When Collective- and Self-Efficacy Affect Team Performance: The Role of Task Interdependence. Small Group Research, 36(4): 437-465. Doi: $10.1177 / 1046496405275233$ 


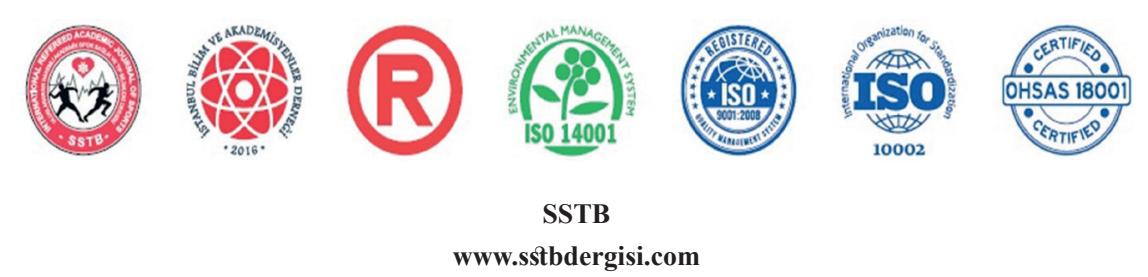

International Refereed Academic Journal of Sports, Health and Medical Sciences

January - February - March Issue 22 Winter Season Year: 2017

JEL CODE: I0-I00-I23-M10-M12-M19 ID:333 K:129

ISSN Print: 2146-8508 Online 2147-1711

(ISO 18001-OH-0090-13001706 / ISO 14001-EM-0090-13001706 / ISO 9001-QM-0090-13001706 / ISO 10002-CM-0090-13001706)

(TRADEMARK)

(2015/04315- 2015-GE-18972)

YÜCEL, A.S., KORKMAZ, M., ÇOBAN, F., (2013). The analysis of collective efficacy perceptions of athletes playing in table tennis leagues in Turkey in terms of some variables, Middle-East Journal of Scientific Research 16 (10): 1403-1412. Doi: 10.5829/idosi.mejsr.2013.16.10.12013

RIGGS, M.L., WARKA, J., BABASA, B, BETANCOURT, R., HOOKER, $S$., (1994). Development and Validation of Self Efficacy and Outcome Expectancy Scale For Job-Related Applications. Educational and Psychology Measurement, 54, 793-802. Doi: $10.1177 / 0013164494054003026$

CARRON, A.V., SHAPCOTT, K.M., BURKE, A.M., (2007). Group cohesion in sport and exercise. Past, present and future. In Beauchamp MR. Eys MA. Group Dynamics in Exercise and Sport Psychology. New York: Routledge. Pp. 117-139

KURT, T., (2012). Öğretmenlerin öz yeterlik ve kolektif yeterlik algıları, Türk Eğitim Bilimleri Dergisi, 10(2): 195-227
RAMZANINEZHAD, R., KESHTAN, M.H., SHAHAMAT, M.D., KORDSHOOLI, S.S., (2009). The relationship between collective efficacy, group cohesion and team performance in professional volleyball teams. Brazilian Journal of Biomotricity, 3(1): 31-39

SAFKAN, $\ddot{U}$., (2010). Elit ve elit olmayan takımlarda kolektif yeterlik, Master's Thesis, Mersin University, Institute of Health Sciences, p. 8

ÖCEL, H., (2002). Takım sporu yapan oyuncularda kollektif yeterlik öz-yeterlik ve sargınlık ile başarı algı ve beklentileri arasındaki ilişkiler, Master's Thesis, Ankara: Hacettepe University, Institute of Social Sciences

ATALAY, A., YÜCEL, A.S., KORKMAZ, M.., KOÇAK, M., KIRTEPE, A., KARATAŞ, $\ddot{O}$., (2015). Futsal oyuncularının kolektif yeterlik algılarının bazı değişkenler açısından incelenmesi, International Refereed Academic Journal of Sports, Volume: 5 No: 16, 108-135, Doi: 10.17363/ SSTB.20151610879 